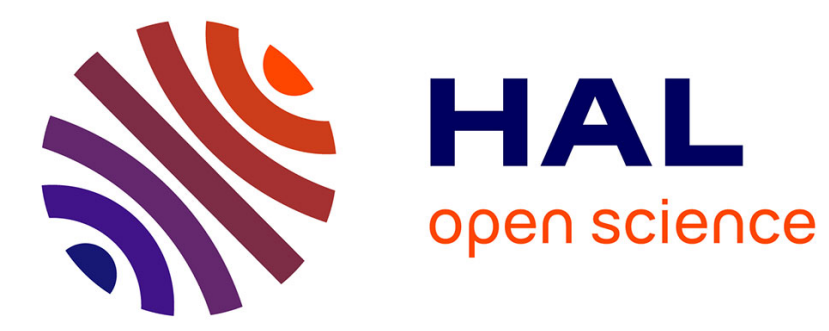

\title{
Performance of an inverted sputter source
}

G. Vourvopoulos, O. Topikoglou, A. Asthenopoulos

\section{To cite this version:}

G. Vourvopoulos, O. Topikoglou, A. Asthenopoulos. Performance of an inverted sputter source. Revue de Physique Appliquée, 1977, 12 (10), pp.1463-1464. 10.1051/rphysap:0197700120100146300 . jpa00244348

\section{HAL Id: jpa-00244348 https://hal.science/jpa-00244348}

Submitted on 1 Jan 1977

HAL is a multi-disciplinary open access archive for the deposit and dissemination of scientific research documents, whether they are published or not. The documents may come from teaching and research institutions in France or abroad, or from public or private research centers.
L'archive ouverte pluridisciplinaire HAL, est destinée au dépôt et à la diffusion de documents scientifiques de niveau recherche, publiés ou non, émanant des établissements d'enseignement et de recherche français ou étrangers, des laboratoires publics ou privés. 


\title{
PERFORMANCE OF AN INVERTED SPUTTER SOURCE
}

\author{
G. VOURVOPOULOS, O. TOPIKOGLOU and A. ASTHENOPOULOS \\ Tandem Accelerator Laboratory, NRC Demokritos \\ Aghia Paraskevi-Attikis, Greece
}

\begin{abstract}
Résumé. - Pour la production d'ions lourds, nous avons construit et installé sur l'accélérateur TANDEM de NRC Demokritos, une source sputtering renversée. Avec cette source les ions négatifs qui, dans les sources sputtering normales, vont vers l'ioniseur sont utilisés comme faisceau. La source produit un nombre d'ions lourds en quantité suffisante sans érosion significative de l'ioniseur.

Pour comparer la qualité du faisceau, on a transmit un faisceau d'oxygène produit par la source renversée et la source diode. Le même pourcentage de transmission à travers l'accélérateur a été observé, indiquant une qualité de faisceau similaire pour les deux sources.
\end{abstract}

\begin{abstract}
An inverted sputter source manufactured locally was installed on the Demokritos Tandem for heavy ion production. The source is utilizing as an extracted beam the negative ions that are found to be back streaming towards the ionizer in a regular sputter source. The source produces in sufficient quantities a number of ion species with rather few signs of ionizer erosion. Concerning the quality of the beam, direct comparison of the transmission through the accelerator of an oxygen beam produced by the sputter source and a diode source indicates the same percentage of transmission.
\end{abstract}

The need to produce a number of heavy ion species reliably and in large quantities led to the decision of installing a sputter source on the Demokritos Tandem. The choice of the inverted sputter source from among the available sputter sources was due to the favorable comments on its performance by our physicist colleagues at Florida State University and the availability of its drawings for local manufacturing. The inverted sputter source [1] utilizes as an extracted beam, the negative ions that are found to be back streaming towards the ionizer in a regular sputter source. As shown in figure 1, in the inverted sputter source developed by K. Chapman the positive cae-

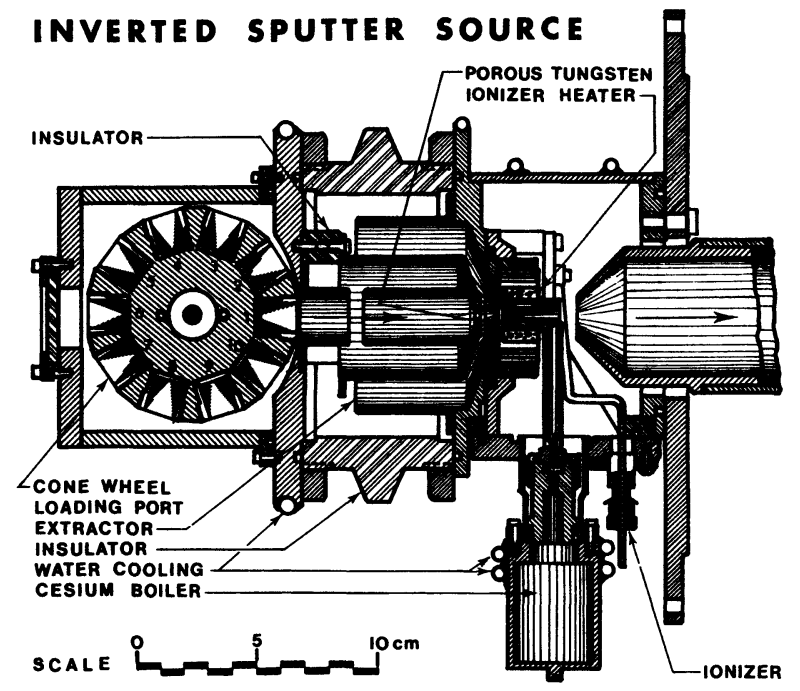

Fig. 1. - INVERTED SPUTTER SOURCE. sium beam is accelerated towards the cone and the negative ions sputtered from the cone pass through the center hole of the ionizer forming the extracted beam. The positive caesium beam with its space charge helps to focus the negative sputtered beam, preventing it from hitting and eroding the ionizer.

The source was manufactured at our Tandem machine shop, from drawings kindly provided by $\mathrm{K}$. Chapman. Its construction required approximately 1000 man hours. Since there is only one pre-accelerator tube available on the Tandem, the source was manufactured so that we could interchange between the inverted sputter source and the diode source utilized for large proton current production. The addition of two supplies was necessary and the change over from the one source to the other is performed during a regular maintenance period.

Several features of the source make it easy to operate, namely the ease of changing or installing new cones through the loading port without disassembling the source, and the incorporation of the caesium boiler, Pierce electrode and ionizer onto one assembly easy to remove and service apart from the remaining of the source.

Table I shows various ion species extracted from the inverted sputter source. Due to the limited terminal voltage of the Tandem $(5.5 \mathrm{MV})$ there is no demand of developing beams heavier than $A=20$ at this time. The maxima of the beam intensities seem to occur at about $9.5 \mathrm{kV}$ extractor voltage independent of the oven temperature. Also, this voltage is lower than the $13 \mathrm{kV}$ expected from the beam quality mea- 
TABLE I. - Parameters for ion species extracted from the inverted sputter source.

\begin{tabular}{|c|c|c|c|c|c|c|c|c|}
\hline Ion & $\begin{array}{l}\text { Heater } \\
\left.{ }^{(} \mathrm{C}\right)\end{array}$ & $\begin{array}{l}\text { Betracto } \\
\text { Voltage }\end{array}$ & $\begin{array}{l}\text { stractor } \\
\text { current }\end{array}$ & $\begin{array}{l}\text { I Tonizer } \\
\text { Heater }\end{array}$ & \begin{tabular}{|l|} 
Cas \\
Pressure
\end{tabular} & $\begin{array}{l}\text { Inflector } \\
\text { aurrent }\end{array}$ & $\begin{array}{l}\text { L.E. } \\
\text { aurren }\end{array}$ & $\begin{array}{l}\text { Thpe } \\
\text { of onne }\end{array}$ \\
\hline & & & & & 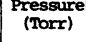 & & $\begin{array}{c}\text { acrrent } \\
\text { (mal) }\end{array}$ & \\
\hline${ }^{12} \mathrm{C}$ & 270 & 9.5 & 1 & 26.8 & - & 19.72 & 14 & C \\
\hline${ }^{7} \mathrm{Li}$ & 260 & 9.5 & 1 & 26.8 & - & 14.8 & 0.3 & Li \\
\hline $1 H$ & 270 & 9.5 & 2 & 26.8 & $1.8 \times 10^{-5}$ & 5.5 & 3.6 & $\mathrm{Ca}$ \\
\hline${ }^{10} \mathrm{~B}$ & 270 & 9.5 & 1 & 26.8 & - & 17.6 & 0.42 & B \\
\hline${ }^{16} 0$ & 270 & 9.5 & 1.2 & 26.8 & $6 \times 10^{-6}$ & 22.5 & 20 & $\mathrm{Ti}$ \\
\hline
\end{tabular}

surements performed on the source by G. Doucas et al. [2].

Examination of the ionizer has shown small signs of erosion after 400 hours of operation, indicating that the beam is well focussed as it passes through the $3 \mathrm{~mm}$ ionizer hole.

Actual emittance measurements of the beam performed at Oxford [2] indicate the emittance of $30 \%$ of the beam is $6 \mathrm{~mm}$. mrad. $\mathrm{MeV}^{1 / 2}$ We could not perform any similar tests at our laboratory but we could make a direct comparison between the diode source and the inverted sputter source. For an oxygen beam produced from either source and for a terminal voltage of $4 \mathrm{MV}$, the transmission through the accelerator was found to be the same, producing the same analyzed current of a given charged state.

We find the overall performance of the inverted sputter source satisfactory and with the automated heating and cooling cycles installed on it, easy to operate in a reliable manner.

\section{References}

[1] Chapman K. R., IEEE Trans Nucl. Sci. N5-23 (1976) 1109.

[2] Doucas G., Hyder H. R. M., Knox A. B., Nucl. Phys. Lab. University of Oxford, Report, june 1975. 